\title{
Covid-19: Implications for Corporate Governance and Corporate Social Responsibility (CSR) in Africa
}

\author{
Misbau Alamu Lateef, Adedoyin Olusegun Akinsulore \\ Faculty of Law, Obafemi Awolowo University, Ile-Ife, Nigeria \\ Email:malateef@oauife.edu.ng, adakinsulore@oauife.edu.ng
}

How to cite this paper: Lateef, M. A., \& Akinsulore, A. O. (2021). Covid-19: Implications for Corporate Governance and Corporate Social Responsibility (CSR) in Africa. Beijing Law Review, 12, 139-160. https://doi.org/10.4236/blr.2021.121008

Received: February 2, 2021

Accepted: March 13, 2021

Published: March 16, 2021

Copyright (๑) 2021 by author(s) and Scientific Research Publishing Inc. This work is licensed under the Creative Commons Attribution International License (CC BY 4.0).

http://creativecommons.org/licenses/by/4.0/

\section{(c) (i) Open Access}

\begin{abstract}
The novel coronavirus disease (COVID-19) has undoubtedly brought a lot of disruptions into the world order-lives, livelihoods, national, and international economies and imposed what is now permeating as the "new normal" in all aspects of human activities. In Africa, the combination of severe health and economic crisis has forced governments to resort to issuing different fiscal and monetary measures as they grapple with the debilitating effects of COVID-19 pandemic on their people and economies, struggle to manage economic recessions, and prepare for a post-COVID-19 regeneration. For businesses, the impacts have not been less disruptive as the shocks and waves of uncertainties continue. As corporations battle to survive and sustain business continuity, the rates of corporate bankruptcy and insolvency mid and post COVID-19 remain speculative and uncertain. Yet the strategic roles of modern corporations in the socio-economic development of society, given the sheer volume of their economic resources alone-something that now makes some corporations more economically powerful than some states, have long been established. Drawing insights from the stakeholder's theories of corporate governance and corporate social responsibility (CSR), this article examines the implications of COVID-19 for corporate governance and CSR, as well as the responses of corporations in Africa to deal with, support, and complement governments' efforts in combating the pandemic's menaces. It attempts to outline some of the challenges and significant improvements that are necessary to shape the future of corporate laws and legal reforms in Africa. The article concludes that sound corporate governance practice and corporate investment in CSR can help to shape the performance and resilience of corporations in Africa to adverse shocks such as the present COVID-19 pandemic.
\end{abstract}




\section{Keywords}

Africa, Corporate Governance, CSR, COVID-19

\section{Introduction}

The view expressed by the famous Nobel Laureate Economist, Milton Friedman, in a 1970 piece in the New York Times that social responsibility of a corporation is to make money for its shareholders, and that anything to the contrary was a "subversive" threat to the very foundation of a free enterprise society (Friedman, 1970), held sway for a long time to justify the rejection of the idea of CSR and failure of corporations to play significant roles in the socio-economic development of their society. But this rather conservative notion (i.e. shareholder primacy) has since been displaced and now overtaken by a much temperate view that businesses as critical stakeholders (stakeholderism) in the society do have social responsibility. Corporations now strive and compete to be good corporate citizens through engagement in sound corporate governance practices and CSR (Donaldson \& Preston, 1995; Siefurt, Morris, \& Bartkus, 2003).

In other words, the notion that corporations are entities for profit-making for the shareholders only has long been dismissed and is no longer fashionable. As critical stakeholders in every economy, corporations, whether national or multinational, are now expected to strive to be good corporate citizens who strike the appropriate balance between their shareholders' values and stakeholders' interests (Abraham, 1995). Thus, the real test of a corporation's consideration for the stakeholders and resilience of its corporate governance (corporate executive leadership and management) and corporate investment in Corporate Social Responsibility (CSR) are put to an enormous task at a time of socio-economic crisis in the society. From Egypt (Africanews, 2020), where the first reported case of COVID-19 pandemic in Africa occurred, to the Republic of South Africa (WHO, 2020b), ${ }^{1}$ which is now the epicentre of the pandemic in the region, COVID-19 has remained a significant source of socio-economic disruptions in Africa in the year 2020 (UNECA, 2020b). Since the first case in Egypt, at least 52 more countries in Africa have reported and still continue to report cases to date. According to the United Nations Economic Commission for Africa (UNECA), as a result of the considerable economic damage, social costs, and compromised over-all well-being inflicted by COVID-19 pandemic, the average GDP growth in Africa in 2020 is expected to fall from $3.2 \%$ to $1.8 \%$ or worse (UNECA, 2020c).

A significant exit strategy to combat the pandemic is the lockdown measures being implemented by many countries across regions. Maintaining a lockdown poses a lot of disruptions in the economy with immediate and long-term eco${ }^{1}$ With 381,789 reported cases of COVID-19 in the Republic of South Africa as at 22 July 2020, the country remains the epicentre of the pandemic in Africa and now ranked the fifth in the world, with only the United States of America $(3,748,248)$, Brazil $(2,098,389)$, India $(1,155,191)$, and the Russian Federation $(783,328)$, ahead in terms of case numbers. 
nomic costs on people and businesses. These measures have disrupted tourism, trade, business operations, and global supply chains. According to the International Monetary Fund (IMF), the anticipated recession of "The Great Lockdown of 2020 " is estimated at $-3 \%$ compared to $-0.1 \%$ during the global financial crisis of 2009 (IMF, 2020). Unlike the previous global economic crises that were triggered by corporate failures, financial imbalances, and governance issues leading to excessive business risks, amongst other causes, the present year 2020 global financial crisis was triggered by an abrupt health pandemic that has succeeded in severe constriction of global economic activities (Bernanke, 2020).

In the first comprehensive survey on COVID-19 and its economic impacts on businesses across Africa, the African Trade Policy Centre (ATPC) of UNECA and International Economic Consulting Ltd. reported that "four-fifths of the respondents (businesses) indicated being significantly affected by the current COVID-19 crisis (rating the effect as 'highly severe or severe') (UNECA, 2020a), and that businesses closed for "lack of operational cash flows, drop in demand, and reduction of opportunities to meet new customers are the main challenges faced by African businesses (ibid, UNECA, 2020a)." Furthermore, it was projected that, in the worst scenario, economic activity for Africa as a whole would contract by 2.6 percent, with negative impacts on the employment rate in particular (UNECA, 2020b). While the fatality in Africa on account of the pandemic has been less severe, with 8779 deaths and 520,373 confirmed infections in 52 countries as at 12 June 2020 (WHO, 2020a), the situation with the economies have been worse for obvious reasons. The African Development Bank (AfDB) actually predicted an economic contraction of up to 3.4 percent for the whole continent in 2020 (AfDB, 2020; Cocks \& Kumwenda-Mtambo, 2020). ${ }^{2}$

In Africa, just like in most developing economies of the world, the main actors in the management and development of state economies are governments, corporations (Roy, 2020), and the aid community like the World Bank, IMF, World Trade Organisations, AfDB, and individual donor countries (Belot, 1995; Sanders, 2000; Edwards, 2001). Being a significant factor in the economic development of the state places corporations at the centre of state policy debates and national problem-solving radius, it is therefore understandable that corporations, particularly multinational corporations, can play a crucial role in complementing governments' efforts to regenerate the economies of states during and post COVID-19 pandemic. After all, corporations, much like governments, provide jobs, salaries, social amenities, products and services amongst others.

Save for the Republic of South Africa ${ }^{3}$ and the Republic of Mauritius (Bissoon,

${ }^{2}$ As at the same period (12 June 2020), 418,294 COVID-19-related deaths and 7,420,520 laboratory-confirmed COVID-19 cases had been registered globally. Meanwhile, as at Friday $7^{\text {th }}$ August 2020, the COVID-19 confirmed cases in Africa has crossed above one million at 1,003,056, of which 21,983 have died and 676,395 recovered. It is still the lowest on a regional basis even as the Republic of South Africa remains the world's fifth and the epicenter in Africa.

${ }^{3}$ The Companies Act No 71 of 2008, Republic of South Africa. Section 7(d) provides that one of the purposes of the Act is to reaffirm the concept of the company as a means of achieving economic and social benefits. 
2018) ${ }^{4}$ where CSR is enshrined in their corporate statutes, CSR is still mostly developing and somewhat amorphous in most African countries (Sarpong, 2017). ${ }^{5}$ Yet, good corporate governance and well-entrenched CSR practices matter in times of crisis, to balance the shareholders' value and stakeholders' interest, and enhance the company's organizational performance in the long run. Indeed, people and the community will not forget the company that supports them in their time of crisis.

Using a doctrinal research methodology of relying on primary and secondary sources of information, this article examines the implications of COVID-19 for corporate governance and CSR, as well as the responses of corporations in Africa to deal with, support, and complement governments' efforts in combating the pandemic's menaces. The article is divided into five parts, including this Introduction as Part I. Part II of the article provides a clear theoretical background to understand the underlying theories used in the article. Part III explores the responsive measures that corporations in Africa have undertaken and are still undertaking to survive and maintain business continuity in the face of the pandemic. Part IV discusses the implications for necessary legal reforms in African countries as part of their efforts to minimise risks and prepare for future challenges. Part V concludes the article and notes there should be proper integration of sound corporate governance practice and CSR into the corporate laws (statutes) and practices in African countries.

\section{Theoretical Background: Corporate Law and Governance}

\subsection{Understanding the Concept of Corporate Governance}

The starting point here is to draw a distinction between corporate law and corporate governance. This distinction and the explanation of corporate law are necessary to lay a proper background for the understanding of corporate governance that will follow subsequently. In its most straightforward understanding, corporate law can be explained as the body of law regulating businesses or governing the operation of corporations in a legal system. In this sense, the idea is primarily about corporate statutes such as the Companies and Allied Matters Act (CAMA) 2020 of Nigeria, the Companies Act 2019 of Ghana, the Companies Act No 712008 of the Republic of South Africa, the Companies Act 2015 of Kenya, ${ }^{6}$ the Companies Law No. 159 of 1981 of Egypt, $^{7}$ the 1960 Commercial

${ }^{4}$ The Companies Act 15 of 2001 was a major revision of companies' legislation since 1984. In Mauritius, corporate bodies are required to operate a CSR fund in accordance with Section 50L of the Income Tax Act 1995 (ITA). See Ourvashi Bissoon, "CSR in Mauritius: an analysis of annual reports of multinational hotel groups" (2018) 3 (2) Asian Journal of Sustainability and Social Responsibility.

${ }^{5}$ The prevalent practice across Africa is to rely on non-legislative and non-obligatory voluntary codes of corporate governance and CSR issued by foreign organizations and/or the company regulators in the countries.

${ }^{6}$ Act No. 17 2015. This Act was subsequently amended by the Statute Law (Miscellaneous Amendment) Act No. 122019 which came into force on 23 July 2019.

${ }^{7}$ In Egypt, depending on the types of activities, companies may be formed either under the Investment Incentives and Guarantees Law 8 of 1997 (the "Original Investment Law"), amended by Law 17 of 2015 and its Executive Regulations 1820 of 2015 (the "New Investment Law") (these laws are hereinafter referred to collectively as the "Investment Law"), or the Capital Market Law 92 of 1995 (the "Capital Market Law"). Representative offices may also be required to be formed under the Commercial Agency Law 120 of 1982 (the "Commercial Agency Law"). 
Code of Ethiopia and the Ethiopian Investment Laws (Ahmed, 2012), amongst others. In all of these countries and others in Africa, there are generally other dispersed laws for the formation of different corporate entities ranging from Limited Liability Companies, Sole Proprietorships, Partnerships, General Partnerships, Limited Partnerships, and Joint Ventures. But is corporate law the same thing as corporate governance? Scholars have expressed divergent views on this.

In 1962, Bayless Manning (Manning, 1962) curiously announced the death of corporate law in America in a somewhat magisterial candour. According to him, corporation law as a field of intellectual effort died in the United States when American law ceased to take the "corporation" seriously. Consequently, the entire body of law that had been built upon that intellectual construct slowly perforated and rotted away leaving "empty corporation statutes-towering skyscrapers of rusted girders, internally welded together and containing nothing but wind (Ibid, Manning, 1962: p. 245).” However, Manning did not stop there as he also extended his bemoaning of the death or failure of corporate law abroad by sounding a note of warning transcending the American geographic to overseas.

Similarly, Ronald Gilson, in his seminal paper titled "From Corporate Law to Corporate Governance," argued forcefully that corporate law became corporate governance "from legal rules standing alone to legal rules interacting with non-legal processes and institutions (Gilson, 2018)." Gilson traced the evolution of corporate law to corporate governance, which, according to a review, "reflects a move from a simple legal view of the corporation to one that has become increasingly complex and dynamic, responding to the increased complexity and dynamics of the capital, input (Lateef et al., 2018; Okorodudu, 1985), ${ }^{8}$ and product markets that corporations inhabit (Gilson, 2017)."

A view that is sharply in contrast with that of Gilson and Manning above, has posited that corporate law as encapsulated in the statute books is entirely different from and superior to corporate governance (Amupitan, 2017). He opined that both corporate law and corporate governance are at best complimentary concepts, with corporate law serving as the foundation for development of corporate governance.

Contrary to the above postulations on the death or transmutation of corporate law, there is also the argument that corporate law (statute) is just one thing while corporate governance-a latter development-is another. That is, while corporate law can be said to represent the structure or outlook of corporate manage-

\footnotetext{
${ }^{8}$ The casual reference here to "input" by Gilson will hardly pass as such in the view of "industrial democracy" scholars. The Industrial democracy scholars argue compellingly that the constituents of corporate organisations actually encompass a broad range of participants comprising not only the shareholders as providers of capital but also the workers as the contributors of labour and as "substantive component of the corporate entity." In sum, "the concept expresses a legal recognition for the multilateral interests of the shareholders and employees - groups which are jointly fundamental, to the very existence these "rights and duties" bearing industrial organisations'. See generally M.T. Okorodudu, "Legal Theory of Incorporation and the Concept of Industrial Democracy', (1985) 5JPPL 29-43; M.A. Lateef, N.K. Adegbite, and Jubril Farinde, "Defining Corporate Governance and Understanding its basic underlying Theories" (2018) 14 (1) Abuad Journal of Public and International Law 17.
} 
ment as comprised in the formality of statutory language and case law, "corporate governance is the corporation's operating system, a braided framework encompassing legal and non-legal elements (Ibid, Gilson, 2018)". For example, the OECD Principles of Corporate Governance ${ }^{9}$ and the Cadbury Report, ${ }^{10}$ two significant prescriptive codes and documents on corporate governance, have extensive coverage and global appeal beyond the limited coverage of the national or domestic corporate statute of any state.

Although the debate about the death or transmutation or independence of corporate law from corporate governance is fascinating and remains controversial, there is no doubt that corporate laws (statutes), with their mandatory legal bites, do also influence corporations a great deal to recognize and protect the interest of the stakeholders, and shape the relationship between the shareholders and the stakeholders on the one hand, and the pursuit of the underlying objectives of the company for achieving good corporate governance, on the other hand. This exact objective of corporate law to shape corporate governance, it can be argued, is precisely what the Ghana Companies Act 2019, for example, seeks to do by introducing improved corporate governance standards for companies operating in the country. By introducing international best practices, the Act draws on the experience of more developed jurisdictions such as the United Kingdom, New Zealand, South Africa, and Mauritius.

\subsubsection{What Then Is Corporate Governance?}

In contradistinction with corporate law (statute) simpliciter, corporate governance as a concept is a multidisciplinary subject. From law to economics to accounting to sociology, and political science, the subject has been variously defined (Thomsen, 2008). The famous 1992 Cadbury Report defines corporate governance as follows:

The system by which companies are directed and controlled. Boards of directors are responsible for the governance of their companies. The shareholders' role in the governance is to appoint the directors and the auditors and to satisfy themselves that an appropriate governance structure is in place. The responsibilities of the board include setting the company's strategic aims, providing the leadership to put them into effect, supervising the management of the business and reporting to shareholders on their stewardship. The board's actions are subject to laws, regulations and the shareholders in the general meeting.

\footnotetext{
${ }^{9}$ Developed by the Organisation for Economic Corporation and Development (OECD), an influential international and intergovernmental economic Organisation, established to set a benchmark for standard setting provide best practice recommendations on corporate governance.

${ }^{10}$ Titled "Financial Aspect of Corporate Governance', was issued in the United Kingdom in December 1992 by "The Committee on Financial Aspects of Corporate Governance" under the chairmanship of Adrian Cadbury in the United Kingdom. It was the foremost pioneer report on corporate governance which had also succeeded in stimulating the development of other subsequent codes of corporate governance such as those of the OECD, the European Union, and World Bank amongst others.
} 
The OECD also provides a functional definition of corporate governance as:

The system by which business corporations are directed and controlled. The corporate governance structure specifies the distribution of rights and responsibilities among different participants in the corporation, such as the board, managers, shareholders and other stakeholders, and spells out the rules and procedures for making decision on corporate affairs. By doing this, it also provides the structure through which the company objectives are set, and the means of attaining those objectives and monitoring performance (OECD).

The above definitions have made one point very clear: corporate governance is the exercise of power in the management of corporations. Put differently, corporate governance is the system by which corporations are governed. It is also a relational control between corporate entities, their managers, and some other constituencies or stakeholders that are both internal and external to corporations. In the next paragraph, we will discuss the stakeholder theory of corporate governance as a conceptual foundation of this article's discussions.

\subsubsection{The Stakeholder Theory of Corporate Governance}

There are several theories of corporate governance and they typically comprise the "Agency theory', "the Stewardship theory', and "the Stakeholder theory', amongst others (Clarke, 2004a). Although the Agency theory of the firm (Berle \& Means, 1932) seems the dominant of all, the "stakeholder theory has a historical lineage, practical applications, and intellectual appeal more substantial than agency theory (Clarke, 2004b)." But much like the Agency theory, the stakeholder theory of the firm has existed in various forms and has been based on different economic principles. In her book titled "The Theory of the Growth of the Firm', Edith Penrose (1959) laid the intellectual foundations for stakeholder theory when she conceptualized a corporation as a bundle of human assets and relationships. However, the term stakeholder theory was first used in 1963 at the Stanford Research Institute, by Igor Ansoff and Robert Stewart, in their analysis of the corporate planning process (Freeman \& Reed, 1983). According to Ansoff:

While...responsibilities and objectives are not synonymous, they have been made one in a "stakeholder theory" of objectives. This theory maintains that the objectives of the company should be derived by balancing the conflicting claims of the various "stakeholders" in the firm, managers, workers, stockholders, suppliers, vendors (Ansoff, 1965).

The agitation that corporations should move from shareholder value maximisation to stakeholder governance is the springboard for the development of the stakeholder theory of corporate governance. The stakeholder theory of corporate governance, in its simplest understanding, posits that, a corporation is a multilateral agreement between the enterprise itself and other multiple stakeholders whose interests and aspirations the corporate must always factor into its gover- 
nance. These stakeholders are often classified into internal and external. The internal stakeholders of a corporation are typically comprised of the owners, managers, and employees, while the external stakeholders are typically comprised of customers, suppliers, creditors, competitors, and the community.

Furthermore, the stakeholder theory of corporate governance can be considered in at least two dimensions. First, are those who say that corporate governance is all about building effective mechanisms to meet or satisfy the expectations of variety of individuals, groups, or entities that are broadly regarded as stakeholders of the company because of their inevitable and constant interaction with the company (Dodd, 1932)? Second, those who focus on the theory only in relation to the narrower expectations of the shareholders (Berle, 1931; Berle, 1932).

In their article, Steve Letza, Xiuping Sun, and James Kirkbride (Letza, Sun, \& Kirkbride, 2004) explain the difference between the "shareholding" and "stakeholding" paradigms of corporate governance as a division which hinges on the purpose of the corporation and its associated structure of governance arrangements understood and justified in theory. On one side is "the traditional shareholding perspective, which regards the corporation as a legal instrument for shareholders to maximize their own investments-investment returns. A three-tier hierarchical structure, i.e. the shareholder general meeting, the board of directors and executive managers, is given in company law in an attempt to secure shareholders' interests... On the other side is the stakeholding perspective newly emerged in the later 20th century, which positions itself on the contrary to the traditional wisdom and views the corporation as a locus in relation to wider external shareholders' interests rather than merely shareholders' wealth. Employees, creditors, suppliers, customers and the local community are major stakeholders often mentioned and emphasized within a broad definition of stakeholding (Ibid, Letza, Sun, \& Kirkbride, 2004: pp. 242-243).”

In the preamble to its revised 2004 OECD Principles of Corporate Governance, the OECD had long recognised the central place of stakeholders in corporate governance. Thus, it states clearly that corporate governance involves a set of relationships between a company's management, its board, its shareholders and other stakeholders. Furthermore, it provides the structure through which the objectives of the company are set, and the means of attaining those objectives and monitoring performance are determined.

The stakeholder theory also provides the basis for the development and promotion of the concept of industrial democracy which addresses the issue of democratization of decision-making process to accommodate workers in corporate management; and the development of CSR, which is the consideration of broader stakeholders beyond the traditional spectrum of maximisation of shareholders profits. Thus, the stakeholder becomes more attractive and persuasive in the explanation of the role of corporate governance in the free market economy. The theory's postulation further suggests that in order to maximise the total wealth 
created by the enterprise as against just the sole interest of the shareholders, management of corporations must take into account the effect of corporate decisions on all stakeholders of the firm. However, stakeholders must be clearly defined and equally identified as those who have contributed firm-specific assets that are at risk in the enterprise (Blair, 1996).

Expectedly, the stakeholder theory became prominent because many researchers recognize that the activities of a corporate entity impact on the external environment thereby requiring accountability by the organization to a wider audience beyond the shareholders (Kyereboah-Coleman, 2008). It is to the credit of the theory of corporate governance, therefore, that modern corporations have now come to terms with the reality that they are no longer the instrument of shareholders alone but exist within society and are also responsible to multitudes of stakeholders. However, the stakeholder theory is not without its own fair share of criticisms. It has been suggested, for example, that the theory arbitrarily assumes a single-valued objective (gains that accrue to a firm's constituencies) as if all that is important to measure the performance of a firm are the gains accruable to the so-called stakeholders (Jensen, 2001). The very notion of a stakeholder has also been referred to as a "deceptively simple" (Clarke, 2004a) one with definitions that "range from the highly specific and legal to the general and social (Ibid, Clarke, 2004a: p. 194)." Notwithstanding these criticisms, the commercial necessity of accepting and embracing the stakeholder theory "in a world where competitive advantage stemmed more and more from the intangible values embodied in human and social capital" (Plender, 1997), is imperative.

\subsubsection{Corporate Governance and the Issues of Divergence and Convergence in Africa}

In Africa, there are several publications on the nature and system of corporate governance on the continent (Ayogu, 2001). In almost all of these publications, the issue of convergence has featured prominently. At the same time, these publications have tried to focus on regulations, legalities, and governance practices across selected African countries (the African countries examined in the study included Nigeria, Botswana, Egypt, Ghana, Kenya, Mauritius, South Africa, Swaziland, Zambia, and Zimbabwe). Often, writings about corporate governance in Africa have dovetailed into reviewing the institutional record of corporate governance in Africa, using what is regarded as the more objective international criteria for the assessment of the quality of corporate governance on the continent. In the study by Ayogu, for example, a broad indicator which included structure of the board, product market competition, structure of ownership, and ownership concentration, was used to conclude that many of the listed firms in Africa belonged to both local and multinationals investors, with little or no information about the ultimate owners in most cases.

This lacuna, according to the study, may well be because politicians might have used their cronies as proxies to stake interest in such corporations, thereby leading to "crony capitalism". The study further concluded that corporate go- 
vernance in Africa may only be enriched when the framework of analysis is expanded beyond the conventional criteria developed from the study of business cultures that do not incorporate the African perspectives. In essence, to properly discuss and understand corporate governance in Africa, the Anglo-American or European models of governance cannot be seen in isolation from the rest of the underpinnings of the African economy. Thus, an expansion of the scope of analysis with the consideration of the non-conventional criteria peculiar to Africa, will improve the understanding of her boardroom dynamics and its inherent decision management and control. In other words, instead of comparing or before importing or exporting corporate governance mechanism, it is important to first examine and understand the peculiar histories, cultural characteristics, and legal traditions of each country. Doing this will help the process of convergence and assimilation as may be desirable and suitable.

Corporate governance systems, it must be emphasized, are generally embedded in the peculiar histories, cultural characteristics, and legal traditions of each country (Pedersen \& Thomsen, 1997). It is this mix, therefore, that interacts in complex ways with other institutions of each country as may also be influenced by different national political dynamics. It is such peculiarities that determine and provide answers to questions like: what happens in countries where there are weak or ineffective institutional mechanisms? What happens in countries where contracts are violated or breached? What happens in countries where fidelity to terms of contracts and enforcement in the event of a breach are questionable? How independent is the judicial systems of such countries? What holds corporations accountable in such countries? How viable are codes of corporate governance?

Most scholarly commentaries on comparative corporate governance have focused on the issues of divergence and convergence, and whether corporate governance systems in different countries are becoming similar to one another from their seeming dissimilarities (Gilson, 2001). Specific classification categories exist for corporate governance models/systems in different regions. In all, the primary point of comparison is the "Anglo-American model" or "Anglo-Saxon capitalism," mainly represented by the UK, US, and Australia. This is the outsider system of the market-based corporate governance system, which is characterised by low ownership concentration or dispersed ownership, one-tier boards, and the primacy of the shareholder value norms. There is almost a consensus that this model is the one to which other countries, including Africa, are gradually assimilating (Bradley et al., 1999). However, it is also possible to argue that the issue of convergence of the corporate governance models is mutual between the seemingly dominant Anglo-American corporate governance model and the European standards which are often characterised by high levels of insider ownership, two-tier boards, and stakeholder concerns (Thomsen, 2003).

Considering the underlying thesis of both the Anglo-American corporate governance model and the European standards focus primarily on the West, they 
are incapable of capturing the perspectives of developing countries in Africa. It is obvious that the challenges of inadequate governance structures amongst others, which corporations face in developing economies are not the same with those in the developed economies whose standards of governance and norms are often characterised as base conditions for any meaningful business climate. But then, there are also other models like the "Emerging Markets model" (Ajogwu, 2007), the "Intermediate Markets"11, and the "Other Markets"12, which also seek to bridge these gaps.

Africa's business environment is significantly characterized by corporate mismanagement, corruption and other challenges. These burgeoning challenges affect the quality of governance structures on the continent when compared with the standards and norms in the developed economies. Africa may only benefit from these models when their framework of analysis is expanded beyond the conventional criteria developed from the study of business cultures in developed economies. Further, there must be a conscious effort to develop an autochthonous African model of corporate governance that is consistent with the dynamics of economic globalisation.

\subsection{Corporate Social Responsibility (CSR)}

CSR, also known as "corporate responsibility", "corporate sustainability", and "social responsibility", in management literature (Klettner, 2016), is a topic that has received increased attention in the last two decades in practice and in theory, both in management and law (William, 2018). CSR is a concept without any single universally agreed definition (Dahlsrud, 2008). However, in one of the earliest attempted definitions, CSR has been defined as "the firm's consideration of, and response to, issues beyond the...economic, technical, and legal requirements of the firm to accomplish social benefits along with the traditional economic gains which the firm seeks (Davies, 1973).” At its simplest, CSR can be defined as a company operating in an economically, socially and environmentally sustainable manner. Put differently, it is a concept which expects boards of corporations to consider, manage, and balance the economic, social, and environmental impacts of their activities. Although there have been many efforts to justify CSR as economically, socially, or legally required (Orentlicher \& Gelatt, 1993; Stephens, 2002) it has remained for the most part, and rightly so, "an ethical, non-legislative, non-forcing approach to promoting responsible behaviours within organisations (Amponsah-Tawiah \& Dartey-Baah, 2011).”

According to Carroll (1999), social responsibilities are those standards, norms, and expectations that reflect a concern for what the society, consumers, employees, shareholders, and other stakeholders regard as fair or just or in keeping with the respect or protection of shareholders' moral rights. This, therefore, is what puts the issue of CSR squarely in the realm of soft laws and norms as

\footnotetext{
${ }^{11}$ This is mainly represented by South Africa, Mexico and Hong Kong amongst others. This particular model is somewhat a hybrid between the Anglo-Saxon and the Emerging markets models.

${ }^{12}$ This is essentially represented by Germany, Japan and Brazil amongst others.
} 
against the hard law. Summing up on the foregoing definitional constructs, the International Organisation for Standardization (ISO) which uses the term corporate responsibility offers a definition that is both practical and comprehensive. It provides thus:

Social responsibility is the responsibility of an organisation for the impacts for its decisions and activities on society and the environment, through transparent and ethical behaviour that:

i) contributes to sustainable development, including the health and the welfare of society;

ii) takes into account the expectations of shareholders;

iii) is in compliance with applicable law and consistent with international norms of behaviour; and

iv) is integrated through the organisation and practiced in its relationship (ISO, 2010).

From the foregoing, it is crystal clear that the term corporate responsibility encompasses not only compliance with legal obligations of companies, environmental and labour law for example, but also voluntary commitment to ethical and sustainable practices that benefit both society and the long-term success of the company (Klettner, 2016).

\subsubsection{The Business Case for CSR}

The subject of CSR is a fertile one and there is a wide literature on the reasons companies might subscribe to such considerations in their governance approaches. This is called the business case or justification for CSR. The proponents of the business case argue that such considerations can improve corporate success through, amongst other things, improving reputation, motivation for employees, and reduction of risks (Anderson, 2005). This position underscores the concept of stakeholder theory earlier discussed above. The stakeholder theory provides the foundation for both the theory and practice of CSR. In practice, following the stakeholder's conception, a corporate behaviour is socially responsible as long as it meets stakeholders' expectations regarding appropriate and acceptable conducts. Thus, it means that corporate responsibility will have a unique meaning for every company and is a dynamic concept that will continue to change depending on changing expectations and circumstances. According to Searcy (Searcy, 2012), corporate sustainability is fundamentally a complex problem and there are no approaches that universally apply. Consequently, "corporations are faced with differing stakeholder demands, continually shifting priorities, and a multitude of alternatives to address their sustainability challenges (Ibid, Searcy, 2012: pp. 239-253)."

The link between corporate governance and CSR has overtime become much stronger. In 2001, Douglas Branson described the emergence of a "new CSR movement, different from previous efforts because of its convergence with good corporate governance (Branson, 2001)." Similarly, KPMG in a 2011 report on 
the state of sustainability reporting concluded that the integration of sustainability or CSR into core business strategy and reporting was the next major development in the field. As sustainability becomes more integrated into business strategy it must also be integrated into existing corporate governance systems (Gill, 2008). In other words, corporate governance is gradually becoming the tool by which public interests concerns are considered in businesses in order to demonstrate corporate good citizenship and commitments to various constituencies.

CSR is not mandated by law in most African countries, where the subject remains largely amorphous or developing. In Nigeria, for example, it is contained in largely dispersed voluntary codes of practices. Noting on the subject of CSR in Nigeria, Abugu states that, "In Nigeria, there appear to be no leading legal or scholarly perspective on the role the modern company should play in the economy. The concept of primacy of shareholders interest still holds sway (Abugu, 2014)." Meanwhile, good corporate practice has come about in large part because of action by various stakeholders and regulators or because companies have received bad publicity from some neglect of their responsibility. This means that the practices of a company may improve or deteriorate depending on the level of volatility in their industry sector, the direction and caliber of their leadership or degree of regulation.

\subsubsection{Regulating CSR}

Given that CSR is a really complex concept that does not lend itself to a globally accepted single definition, it is not surprising that it is also a difficult concept to regulate. Thus, if CSR is defined as voluntary behavious, "the idea that law might make business responsible for social responsibility is paradoxical." However, as it was pointed out earlier in the discussion concerning the Republic of South Africa, this paradox has not stopped legislation of CSR into the body of corporate law and governance statutes. This much has been achieved in the Republic of South Africa ${ }^{13}$, the Republic of Mauritius ${ }^{14}$, amongst others. It has also not stopped the courts from interpreting the law to permit CSR. Also, it has not stopped legal commentators from encouraging CSR through reporting requirements. According to Martin, "the line between CSR and voluntary action and what the law requires is often rather thin: many CSR voluntary actions are underpinned by a strong legislative framework, and many follow directly from it (Martin, 2005)."

\section{Responsive Measures by Corporations in Africa}

Businesses in Africa, home-grown and multinational, have been the worst hit by the incidence of the COVID-19 pandemic. As pointed out in Part I of this article, the pandemic remains a significant source of socio-economic disruptions in Africa in the year 2020. According to several reports with forecasts on the im${ }^{13}$ Section 7 (d) Companies Act No 71 of 2008.

${ }^{14}$ The Companies Act 15 of 2001. 
plications of COVID-19 for businesses in Africa, averagely, businesses in the region report to be operating at only 43 per cent, with larger firms operating at a slightly better capacity. The subsectors of manufacturing, health, entertainment, transport and trade report to be operating at the lowest possible capacities. In all, the top challenges reported by African businesses are comprised in their order of severity as follows: drop in demand for products/services; lack of operational cash flow; reduction of opportunities to meet new customers; closure of business; issues with changing business strategies and offering alternative products/services; decline in workers' production/productivity from working at home; inability of many workers to return to work; challenges in logistics and shipping of products; and difficulties in obtaining supplies of raw materials essential for production.

With such grim reports as the foregoing, survival and business continuity appear the most strategic response of corporations at this time. Thus, while the micro, small and medium-sized enterprises (MSMEs) are primarily concerned by cash flow outlook, the large companies are challenged by the need to adapt their business models to the crisis. With such attention on survival and business continuity, it has been difficult to have any properly coordinated response beyond haphazard corporate philantrophy or charitable giving that has characterised the activities of most companies that can still afford to give at this time. ${ }^{15}$ Indeed, another challenge is that critical decision-making in these times is fraught with uncertainty.

In the theoretical background provided in Part II of this article, the point has been made clearly that the stakeholder theories of corporate governance and CSR justify the responsibility of corporations to meet or satisfy the expectations of the stakeholders. So, how exactly have corporations responded or been responding to negative impacts of the pandemic on people, businesses, and environments in Africa? First, there cannot be a straightforward answer to this query at this time when the full impacts of the pandemic remain speculative and uncertain. This is also because responses have been as diverse and country-specific as the impacts of the pandemic have been. Second, as the pandemic continues to bare its fangs, there are presently no scientific data to provide a definite response to this query.

However, in spite of the above limitations, there are abundant records of how some businesses in Africa have responded with measures ranging from donation of funds, provision of medical and safety kits, food supplies, provision of test kits, and several more. In Nigeria, as in most African countries, not long after the outbreak of the pandemic, corporations, banks, corporate giants, and wealthy individuals quickly stepped in to make donations, and have continued that

\footnotetext{
${ }^{15}$ For years, scholars have documented the use of charitable donations as part of a strategic plan to gain a competitive edge. This has often been labelled as strategic philantrophy, a deliberate corporate giving or philantrophy that is aimed at helping the bottom line. Thus, there are findings showing that a strategic reorientation of a company's CSR philosophy can support its financial interests as well as other stakeholders' interests in the company.
} 
trend to support and complement efforts of government till date (Salaudeen, 2020). From Angola to Botswana ${ }^{16}$ to Egypt (Nassar, 2020) to Ghana (Goldfields, 2020) to Namibia (De Beers Group, 2020) to the Republic of South Africa, amongst several others, the trend has been the same. However, there are also concerns that some corporations, particularly the multinational ones in the mining, oil, gas, and petrochemical industry, may be exploiting the catastrophic global pandemic to aggressively push their preexisting corporate agenda, including regulatory rollbacks, suspension of environmental law enforcement, criminalization of environmental protests, and direct government bailouts in a growing number of countries, even as underlying risks facing the industry, however, remain unchanged (Business \& Human Rights Resource Centre, 2020). To check the possibility of such opportunistic corporate giving and exploitations, there is a need for regulatory institutions in Africa to be vigilant and insist on the right thing always.

Meanwhile, in order to help all businesses globally understand the emerging risks associated with the impact of the COVID-19 pandemic, there have also been concerted efforts across the world by governments and different organisations. The World Economic Forum, in collaboration with Marsh and McLennan and Zurich Insurance Group, has launched a report titled "COVID-19 Risks Outlook: A Preliminary Mapping and its Implications (WEF, 2020a)." The report is a special edition to build-up on the Forum's annual Global Risk Report. In it, they examined the views of nearly 350 senior risk professionals globally who took part in the COVID-19 Risks Perceptions Survey. The risk professionals were all asked to assess 31 risks within three categories, namely: most likely for the world, most concerning for the world, and most worrisome for companies. With specific reference to companies, two-thirds of respondents identified a prolonged recession as a top concern for businesses; one-half identified bankruptcies (big firms and SMEs) and industry consolidation, failure of industries to recover, and a disruption of supply chains. The report therefore recommends continuous collaboration between the public and private sectors to help solve some of the most urgent business and economic challenges associated with the pandemic.

Similarly, PwC, a Strategic Partner of the World Economic Forum, has created a free digital assessment tool called "COVID-19 Navigator (PwC, 2020b)" to help organisations understand the impact of COVID-19 on their businesses, and assess their readiness to respond (WEF, 2020b). This digital tool helps corporations to understand where they stand as they respond to COVID-19 in the areas of crisis management and response; workforce; operations and supply chain; finance and liquidity; tax and trade; strategy and brand. Furthermore, PwC has developed another tool to track the tax, legal, and economic measures undertaken in countries around the world in response ${ }^{16}$ On the $6^{\text {th }}$ April 2020, De Beers Group, a Diamond Company with considerable mining investments in Africa, made an announcement of a \$2,500,000 donation made across Botswana and $\mathrm{Na}$ mibia as relief support towards the public health emergency. 
to the pandemic $(\mathrm{PwC}, 2020 \mathrm{a})$.

\section{Some Implications for Legal Reforms}

If anything, the incidence of COVID-19 pandemic has helped to further expose the inefficient and weak governance processes, deep-rooted inequality, and a lack of social security, permeating African nations. The same thing applies to governance of corporations in the region. Prior to the outbreak of the pandemic in the region, the issues of adherence to standards of corporate governance and CSR were for the best part amorphous. This is particularly so from the perspectives of the corporate statutes in most African countries that are yet to depart from their colonial heritages. To address this challenge, there must be adequate legislative provisions on corporate governance issues related to the separation of supervision and management responsibilities, and on the composition, independence, and remuneration of the board of directors in share companies. While it is conceded that several corporate statutes across Africa now meet this requirement, there are still rooms for corporate law reforms, particularly in the areas of regulations, disclosures, accountability, enforcement, and supervision. For example, a corrupt or lax regulatory system or weak enforcement mechanism will make opportunistic corporations susceptible to exploitation of the system to advance their selfish objectives.

Furthermore, there is a need for reforms in the areas of rule of law, corruption, and the judicial system underpinning the legal systems of African countries. The general consensus is that, for the basic enabling environment for businesses that would lead to business growth and attraction of foreign direct investments to exist, there must be the rule of law, enforceable contracts, and an independent judiciary (Gilson, 2001; Black, 2001). To secure the confidence of investors, for example, they must feel satisfied that there is an independent and impartial judicial system to enforce contracts whenever things go wrong as they sometimes do. In a study, international business executives were asked to list the most important constraints on their firms' growth in developing economies, "corruption and ineffective government bureaucracies were second and third to a lack of finance (Cahn, 2004)" on their list. Without a doubt, the state of the rule of law in any legal system is perhaps the most important prerequisite for responsible corporate governance. In an article where he listed the preconditions for a strong securities market, Black (2001) clearly articulated this point. He laid emphasis on two of them, namely: disclosure of the value of the company and protection against self-dealing. It is only after these basic structures are put in place that debates about value maximization for a corporation can occur. For investors will not come into any economy or engage in CSR activities unless they can maximise the value of their investments. Black concluded by discussing transition economies that have none of the basic institutions necessary to establish the prerequisites for a securities market and recommended the development of a reliable legal system, governmental honesty, capital markets, accounting 
rules, and business schools (Ibid, Black, 2001: pp. 845-846).

Finally, African countries need to industrialize with a view to boosting intra-Africa trade. They also need to exploit the potential role of the fourth industrial revolution to innovate, manage and facilitate governance processes. The recently concluded African Continental Free Trade Agreement (AfCFTA) presents an outstanding opportunity for accelerated progress on the Sustainable Development Goals (SDGs), as expanded intra-African trade, investment, and job creation will lead to greater economic and social development overall. While trading under the AfCFTA that was originally scheduled to commence in July 2020 has been frustrated by the disruptions of the pandemic, all hope is not lost as the agreement's promise will be fulfilled if African governments work together to accelerate the pace of its implementation. Corporations, undoubtedly have roles to play in partnering with governments as important stakeholders.

\section{Conclusion}

Corporations are important stakeholders in the socio-economic development of state economies. The outbreak of COVID-19 pandemic in Africa is now putting to task the resilience of businesses in the face of uncertainty and severe economic downturns. This article has examined the impacts, responses, and legal implications of COVID-19 on businesses in Africa. To develop a good strategy to boost or enhance their corporate immunity to economic shocks arising from the pandemic, this article has discussed the stakeholder theories of corporate governance and CSR to underscore the importance of serious engagement with stakeholders. As corporations are a nexus of contracts between shareholders and other stakeholders (including workers, suppliers, customers, and communities), building good relationships with stakeholders, as good corporate citizens, will enhance and maximise firms' value in the long run.

The article found that with so much attention being placed on survival and business continuity, it has been difficult to have any properly coordinated response beyond haphazard corporate philantrophy or charitable giving that has characterised the activities of most companies at this time. However, as governments and businesses strive to survive, it appears that direct economic support from governments to SMEs and bigger corporations will be a lasting feature of recovery packages. With such efforts, post COVID-19 regeneration of national economies will be easier. It will also help to incentivise the transition to more sustainable and resilient business models and supply chains to strengthen each country's economic fabric ahead of future shocks.

Meanwhile, while focusing on corporate governance in developed countries, the sight must not be lost of the problems in less developed countries. For a proper assimilation or convergence therefore, Africa may only be enriched when the framework of analysis is expanded beyond the conventional criteria developed from the study of business cultures in developed economies. Thus, there must be conscious efforts to develop an autochthonous African model of corpo- 
rate governance that is consistent with the dynamics of economic globalisation. However, African countries must also be prepared to undertake necessary corporate law and legal reforms to guarantee the minimum enabling environment for investors and businesses to thrive. This will also help to ensure proper integration of sound corporate governance practice and CSR into the law and practices in Africa.

Finally, good corporate governance is an important pillar of the market economy and it enhances investors' confidence. At the most general level, good management is obviously crucial to economic efficiency, productivity, firm performance, and social welfare. However, transparency and accountability are crucial corporate governance mechanisms to curb self-interest and opportunistic corporate giving, particularly in a crisis.

\section{Conflicts of Interest}

The authors declare no conflicts of interest regarding the publication of this paper.

\section{References}

Abraham, F. W. (1995). Management's Responsibilities in a Complex World. Harvard Business Review, 29, 54-64.

Abugu, E. O. (2014). Principles of Corporate Law in Nigeria. Lagos: MIJ Professional Publisher.

African Development Bank (AfDB) (July 2020). African Economic Outlook 2020 Amid COVID-19: Supplement.

https://afdb.org/en/documents/african-economic-outlook-2020-supplement

Africanews (14 February, 2020). COVID-19: Egypt Confirms First Coronavirus Case in Africa.

https://www.africanews.com/2020/02/14/covid-19-egypt-confirms-first-coronavirus-ca se-in-africa/

Ahmed, T. H. (2012). Overview of Corporate Governance in Ethiopia: The Role, Composition and Remuneration of Boards of Directors in Share Companies. Mizan Law Review, 6, 45-76. https://doi.org/10.4314/mlr.v6i1.2

Ajogwu, A. (2007). Corporate Governance in Nigeria: Law and Practice. Centre for Commercial Law Development.

Amponsah-Tawiah, K., \& Dartey-Baah, K. (2011). Corporate Social Responsibility in Ghana. International Journal of Business and Social Science, 2, 107-112.

Amupitan, J. O. (2017). Nigerian Corporate Governance: From Concentrated Ownership to Dispersed Ownership-Which Way Forward? In Unijos Inaugural Lecture Series (Vol. 70). Jos: University of Jos.

Anderson, H. (2005). Corporate Social Responsibility: Some Critical Questions for Australia. University of Tasmania Law Review, 24, 143-172.

Ansoff, I. (1965). Corporate Strategy. New York: McGraw-Hill.

Ayogu, M. D. (2001). Corporate Governance in Africa: The Record and Policies for Good Governance. African Development Review, 13, 308-330.

https://doi.org/10.1111/1467-8268.00041 
Belot, A. I. (1995). The Role of the IMF and the World Bank in Rebuilding the CIS. TICLJ, 9, 83-84.

Berle, A. A. (1931). Corporate Powers as Powers in Trust. Harvard Law Review, 44, 1049-1074. https://doi.org/10.2307/1331341

Berle, A. A. (1932). For Whom Corporate Managers are Trustees: A Note. Harvard Law Review, 45, 1365-1372. https://doi.org/10.2307/1331920

Berle, A. A., \& Means, G. C. (1932). The Modern Corporation and Private Property. New York: Macmillan.

Bernanke, B. (2020). Ben Bernanke on COVID-19 Downturn. Marketplace. https://www.marketplace.org/2020/03/23/former-fed-chair-bernanke-covid19-downtur $\underline{\mathrm{n} /}$

Bissoon, O. (2018). CSR in Mauritius: An Analysis of Annual Reports of Multinational Hotel Groups. Asian Journal of Sustainability and Social Responsibility, 3, Article No. 2. https://doi.org/10.1186/s41180-017-0017-4

Black, S. B. (2001). The Legal and Institutional Preconditions for Strong Securities Market. UCLA Law Review, 48, 781-855.

Blair, M. M. (1996). Wealth Creation and Wealth Sharing: A Colloquium on Corporate Governance and Human Capital. Brookings Institute.

Bradley, M. et al. (1999). The Purposes and Accountability of the Corporation in Contemporary Society. Law \& Contemporary Problems, 62, 9-86. https://doi.org/10.2307/1192226

Branson, D. (2001). Corporate Governance "Reform" and the New CSR. University of Pittsburgh Law Review, 62, 605-647.

Business \& Human Rights Resource Centre (2020). https://www.business-humanrights.org/en/

Cahn, N. (2004). Corporate Governance Divergence and Sub-Saharan Africa: Lessons from out Here in the Fields. Stetson Law Review, 33, 893-924.

Carroll, A. B. (1999). Corporate Social Responsibility: Evolution of a Definitional Construct. Business \& Society, 38, 268-295. https://doi.org/10.1177/000765039903800303

Clarke, T. (2004a). Stakeholder Theory: Introduction to Part Six. In T. Clarke (Ed.), Theories of Corporate Governance (pp. 171-172). Abingdon-on-Thames: Routledge.

Clarke, T. (2004b). The Stakeholder Corporation: A Business Philosophy for the Information Age. In T. Clarke (Ed.), Theories of Corporate Governance (p. 194). Abingdon-on-Thames: Routledge.

Cocks, T., \& Kumwenda-Mtambo, O. (2020). Africa's Cases of COVID-19 Top 1 Million: Reuters Tally. Reuters.

https://www.reuters.com/article/us-health-coronavirus-africa-idUSKCN25235N

Dahlsrud, A. (2008). How Corporate Social Responsibility Is Defined: An Analysis of 37 Definitions. Corporate Social Responsibility and Environmental Management, 15, 1-13. https://doi.org/10.1002/csr.132

Davies, K. (1973). The Case for and against Business Assumption of Social Responsibilities. Academy of Management Journal, 16, 312-323. https://doi.org/10.5465/255331

De Beers Group (2020). De Beers Group Contributes \$2,500,000 across Botswana and Namibia to Support Covid-19 Response.

https://www.debeersgroup.com/media/company-news/2020/de-beers-group-contribut es-\$2500000-across-botswana-and-namibia-to-support-covid-19-response

Dodd, E. M. (1932). For Whom Are Corporate Managers Trustees? Harvard Law Review, 
45, 1145-1163. https://doi.org/10.2307/1331697

Donaldson, T., \& Preston, L. (1995). The Stakeholders Theory of the Corporation: Concepts, Evidence, Implications. Academy of Management Review, 20, 65-91. https://doi.org/10.5465/amr.1995.9503271992

Edwards, M. (2001). Introduction. In M. Edwards, \& J. Gaventa (Eds.), Global Citizen Action (pp. 3-4). Boulder, CO: Lynne Rienner Publishers Inc.

Freeman, R. E., \& Reed, D. L. (1983). Stockholders and Shareholders: A New Perspective on Corporate Governance. California Management Review, 25, 88-106. https://doi.org/10.2307/41165018

Friedman, M. (1970). The Social Responsibility of Business Is to increase Its Profits. New York. Times Magazine, 32-33.

Gill, A. G. (2008). Corporate Governance as Social Responsibility: A Research Agenda. BJIL, 26, 452-478.

Gilson, J. R. (2001). Globalizing Corporate Governance: Convergence of Form or Function. The American Journal of Comparative Law, 49, 329-358. https://doi.org/10.2307/840814

Gilson, R. J. (2017) ECGI Prize, 2017. https://ecgi.global/news/2017-law-prize-corporate-law-corporate-governance

Gilson, R. J. (2018). From Corporate Law to Corporate Governance. In J. N. Gordon, \& R. Wolf-George (Eds.), The Oxford Handbook of Corporate Law and Governance. Oxford: Oxford University Press.

Goldfields (2020). Gold Fields' Damang Mine Supports Host Communities to Fight Covid-19. https://www.goldfields.com/news-article.php?articleID=8994

International Monetary Fund (IMF) (April 2020). World Economic Outlook "Chapter 1, The Great Economic Lockdown". https://www.imf.org/en/Publications/WEO/Issues/2020/04/14/weo-april-2020

International Standard Organisation (ISO) (2010). ISO 26000: 2010-Guidance on Social Responsibility. https://www.iso.org/standard/42546.html

Jensen, M. (2001). Value Maximization, Stakeholders Theory and the Corporate Objective Function. Journal of Applied Corporate Finance, 14, 8-21. https://doi.org/10.1111/j.1745-6622.2001.tb00434.x

Klettner, A. (2016). Corporate Governance Regulation: The Changing Roles and Responsibilities of Boards of Directors. London: Routledge.

https://doi.org/10.4324/9781315693644

Kyereboah-Coleman, A. (2008). Corporate Governance and Firm Performance in Africa: A Dynamic Panel Data Analysis. Studies in Economics and Econometrics, 32, 1-24.

Lateef, M. A., Adegbite, N. K., \& Farinde, J. (2018). Defining Corporate Governance and Understanding Its Basic Underlying Theories. ABUAD Journal of Public and International Law, 14, 17.

Letza, S., Sun, X., \& Kirkbride, J. (2004). Shareholding versus Stakeholding: A Critical Review of Corporate Governance. Corporate Governance: An International Review, 12, 242-243. https://doi.org/10.1111/j.1467-8683.2004.00367.x

Manning, B. (1962). The Shareholders' Appraisal Remedy: An Essay for Frank Coker. The Yale Law Journal, 72, 223-265. https://doi.org/10.2307/794814

Martin, F. (2005). CSR and Public Policy. In R. Mullerat (Ed.), CSR: The Corporate Governance of the 21st century (pp. 77-95). Amsterdam: Netherlands International Bar Association. 
Nassar, M. (2020) Egyptian Firms Embrace CSR by Injecting Millions to Support State in COVID-19 Crisis.

https://www.csregypt.com/en/egyptian-firms-champion-csr-by-injecting-millions-to-s upport-state-in-covid-19-crisis/

Okorodudu, M. T. (1985). Legal Theory of Incorporation and the Concept of Industrial Democracy. JPPL, 5, 29-43.

Orentlicher, F. D., \& Gelatt, A. T. (1993). Public Law, Private Actors: The Impact of Human Rights on Business Investors in China. Northwestern Journal of International Law \& Business, 14, 66.

Pedersen, T., \& Thomsen, S. (1997). European Patterns of Corporate Ownership: A Twelve-Country Study. Journal of International Business Studies, 28, 759-778. https://doi.org/10.1057/palgrave.jibs.8490118

Penrose, E. (1959). The Theory of the Growth of the Firm. Oxford: Oxford University Press.

Plender, J. (1997). A Stake in the Future: The Stakeholding Solution. Boston, MA: Nicholas Brealey Publishing.

PwC (2020a). Navigate Tax, Legal and Economic Measures in Response to COVID-19. https://www.pwc.com/gx/en/services/tax/navigate-the-tax-measures-in-response-to-Co vid-19.html

PwC (2020b). PwC's COVID-19 Navigator. https://www.pwc.com/gx/en/issues/crisis-solutions/covid-19/response-navigator.html

Roy, A. D. (2020). Trends in Global CSR Practices: The Case of Sub-Saharan Africa. IJCS, $8,64-65$.

Salaudeen, A. (2020). Government, Banks, Wealthy Individuals Contribute Billions to Fight Coronavirus in Nigeria. CNN. https://www.edition.cnn.com/2020/03/27/africa/coronavirus-nigeria-fund/index.html

Sanders, J. (2000). The World Bank and the IMF: Fostering Growth in the Global Market. CITLJ, 9, 37.

Sarpong, S. (2017). Corporate Social Responsibility in Ghana: Issues and Concerns. In S. Idowu, S. Vertigans, \& A. Schiopoiu Burlea (Eds.), Corporate Social Responsibility in Times of Crisis (pp. 191-205). Cham: Springer. https://doi.org/10.1007/978-3-319-52839-7_10

Searcy, C. (2012). Corporate Sustainability Performance Measurement Systems: A Review and Research Agenda. Journal of Business Ethics, 107, 239-253. https://doi.org/10.1007/s10551-011-1038-Z

Siefurt B. B., Morris, S., \& Bartkus, B. (2003). Comparing Big Givers and Small Givers: Financial Correlates of Corporate Philanthropy. Journal of Business Ethics, 45, 195-211. https://doi.org/10.1023/A:1024199411807

Stephens, B. (2002). The Amorality of Profit: Transnational Corporations and Human Rights. Berkeley Journal International Law, 45, 62-63.

The 1960 Commercial Code of Ethiopia and the Ethiopian Investment Laws.

The Companies Act 2015 of Kenya.

The Companies Act 2019 of Ghana.

The Companies Act No 712008 of the Republic of South Africa.

The Companies and Allied Matters Act (CAMA) 2020 of Nigeria.

The Companies Law No. 159 of 1981 of Egypt.

Thomsen, S. (2003). The Convergence of Corporate Governance Systems to European 
and Anglo-American Standards. European Business Organization Law Review, 4, 31-50. https://doi.org/10.1017/S1566752903000314

Thomsen, S. (2008). An Introduction to Corporate Governance: Mechanisms and Systems. København: Djøf Publishing.

UNECA (August 2020c). COVID-19 in African Cities: Impacts, Responses and Policies. https://repository.uneca.org/handle/10855/43759

UNECA (July 2020b). COVID-19 in African Cities: Protecting Lives and Economies. https://reliefweb.int/report/algeria/covid-19-africa-protecting-lives-and-economies-ena $\underline{r}$

UNECA (June 2020a). Insights on African Businesses' Reactions and Outlook to COVID-19. https://repository.uneca.org/handle/10855/43780

WHO (2020). Coronavirus Disease (COVID-19) Situation Report-144. https://www.who.int/docs/default-source/coronaviruse/situation-reports/20200612-cov id-19-sitrep-144.pdf?sfvrsn=66ff9f4f_2

WHO (22 July 2020). Situation Update for the WHO African Region. https://reliefweb.int/report/south-africa/covid-19-situation-update-who-african-region -external-situation-report-28-09

William, A. C. (2018). CSR and Corporate Governance. In J. N. Gordon, \& R. Wolf-George (Eds.), The Oxford Handbook of Corporate Law and Governance (p. 634). Oxford: Oxford University Press.

World Economic Forum (2020a). COVID-19 Risks Outlook: A Preliminary Mapping and Its Implications.

https://www.weforum.org/reports/covid-19-risks-outlook-a-preliminary-mapping-and -its-implications

World Economic Forum (2020b). How Are Companies Responding to the Coronavirus Crisis?

https://www.weforum.org/agenda/2020/03/how-are-companies-responding-to-the-cor onavirus-crisis-d15bed6137/ 